\title{
Lithostratigraphy of the Naga-Manipur Hills (Indo-Burma Range) Ophiolite Belt from Ukhrul District, Manipur, India
}

\author{
A Joshi ${ }^{1^{*}}$ and KT Vidyadharan ${ }^{2}$ \\ 1 Geological Survey of India, NH-5P, NIT Faridabad-121001, Haryana, INDIA \\ 2 310, Block "B", Maharaja Residency, Balmatta Road, Hampankatta, Mangalore-575001, INDIA \\ * For correspondence, email: joanil@rediffmail.com
}

Two late Mesozoic ophiolite belts occur along the eastern margin of the Indian plate. The eastern or Sumatra belt is poorly exposed whereas the western or the Indo-Burma Range (Naga-Manipur Hills) ophiolite belt is well preserved particularly in the Myanmar bordering terrain of Manipur. The NE-SW trending western belt extends in the states of Nagaland and Manipur and is about $200 \mathrm{~km}$ wide in north before splitting into thin slices towards south. This study delineates the lithostratigraphic ensemble of the ophiolite belt in the northernmost part of Manipur in Ukhrul district while discussing its petrology and tectonic implications.

Three major lithopackages have been mapped in this area. From west to east these comprise a thick, folded pile of Paleogene sediments, which are tectonically juxtaposed with an ophiolite suite followed by feebly metamorphosed pelagic cover sediments (Figure1). The sedimentary rocks in the west include shale-siltstone rhythmites with minor sandstone (Disang Group) representing distal shelf facies that grades upward to a conglomerate-grit-sandstone-coal streaks-bearing shallow marine to fluviatile sequence (Barail Group). The upper part of Disang Group depicts an olistrostromal zone with olistoliths of mainly fossiliferous limestone, varying in dimensions from a few meters to more than $0.5 \mathrm{~km}$. The foraminiferal assemblage of limestone suggests a wide, upper Cretaceous (Maastrichtian) to Oligocene age range supporting their exotic nature in the mélange zone (Vidyadharan and Joshi 1984, Vidyadharan et al. 1989).

The ophiolite suite exhibits a dismembered sequence with alternating slices of variable dimensions including ultramafics, mafic differentiates and volcanics. Harzburgite is the dominant lithology of the ultramafic clan followed by volumetrically insignificant dunite, and pyroxenite. All ultramafic variants depict various stages of serpentinization with development of magnetite, talc and a typical ribbon and mesh texture. Chromite occurs as massive chromitite bands (metallurgical to refractory grade), nodular pods and disseminations. A significant feature of the peridotite association is the occurrence of thin, discontinuous lenses of coarse, dark coloured garnet bearing ultramafic segregations, with diopside, grossular-almandine garnet, magnesio-hastingsite and rutile as the other major minerals, in the northeastern part of this area. These rocks show strong enrichment of $\mathrm{CaO}$ and severe depletion of $\mathrm{MgO}$ from the host peridotites besides higher values for $\mathrm{Al}_{2} \mathrm{O}_{3}, \mathrm{TiO}_{2}, \mathrm{Na}_{2} \mathrm{O}, \mathrm{K}_{2} \mathrm{O}$ and resemble the metarodingite formed by extensive $\mathrm{Ca}$ metasomatism during serpentinization of the host rocks followed by high pressure recrystallization (Evans et al. 1979). Mafic differentiates are represented mainly by gabbros and plagiogranite. Prolonged rodingisitization of these rocks is displayed by the presence of chlorite, epidote, zoisite and calcite. Massive to amygdaloidal, low $\mathrm{MgO}$ basalts showing intersertal and glomeroporphytitic textures represent the volcanic rocks besides a few occurrences of volcanic agglomerates.

The easternmost unit of this area exposes oceanic pelagic cover sediments comprising mainly phyllite, quartzite, bedded radiolarian chert and limestone. These have undergone low grade metamorphism and also incorporate tectonic slices of the ophiolite suite.

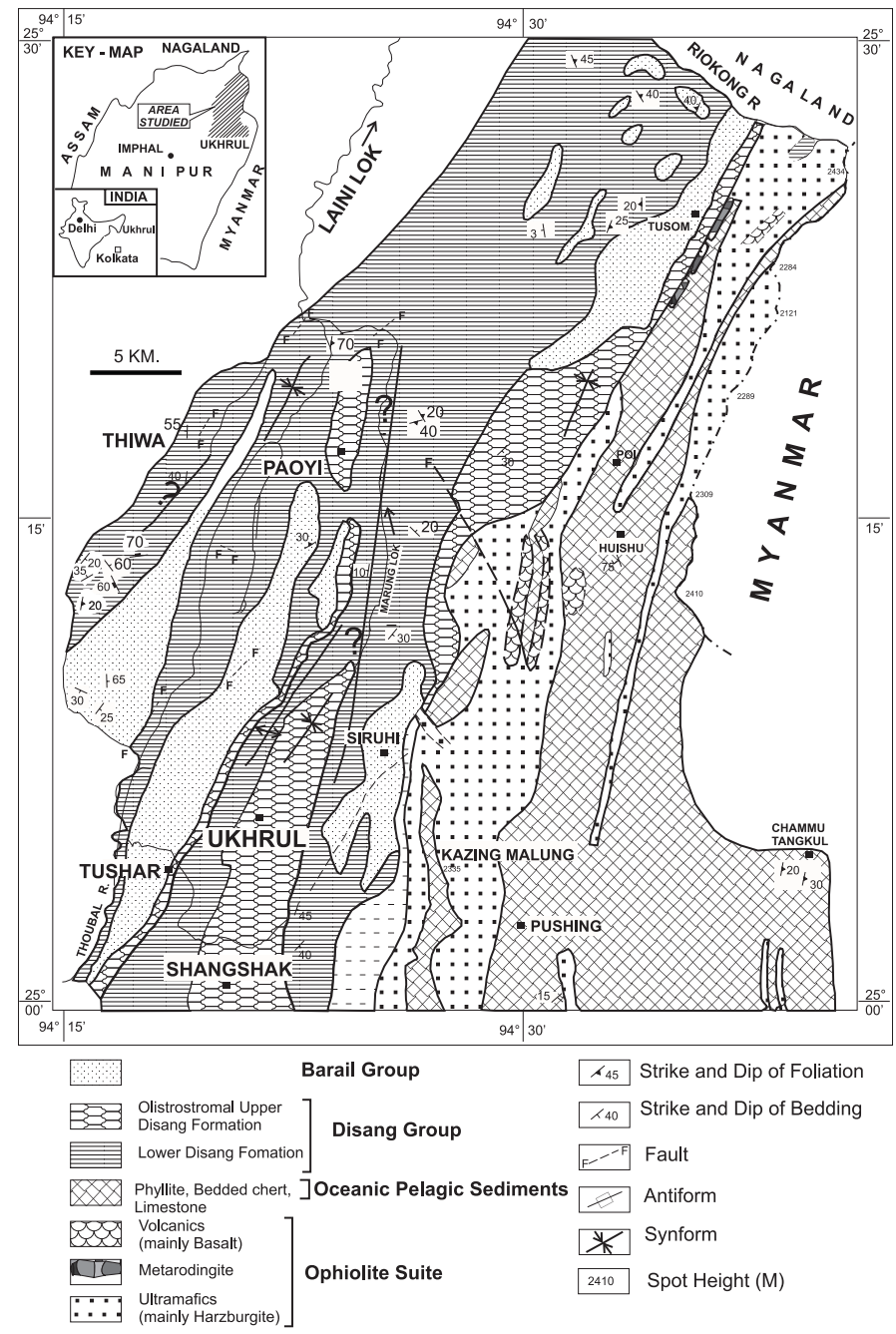

FIGURE 1. Geological map of the area around Ukhrul, NagaManipur Hills, Manipur (Modified after Vidyadharan et al. 1989). 
Absence of dyke swarms and the chemistry of the volcanic rocks indicates an ocean island or seamount type of setting for this belt, whereas presence of metarodingite and glaucophane-bearing schists further north in Nagaland suggests a complex subduction process. Linear zone of negative gravity anomalies over the western ophiolite belt has been explained by shallow nature of these nappes, while linear gravity high over the eastern belt makes it the site of the of the root zone of the eastern suture of Indian plate (Acharyya et al. 1990, Acharyya 2007, Sengupta, 1990).
References

Acharyya SK, KK Ray and DKRoy. 1990. Tectono stratigraphy and emplacement history of the ophiolite assemblage from the Naga Hills and Andaman Island Arc, India. Journal of the Geological Society of India 33: 4-18

Acharyya SK. 2007. Collisional emplacement history of the NagaAndaman ophiolites and the position of the eastern Indian suture. Journal of the Asian Earth Sciences 29: 229-242

Evans BW, V Trommsdorff and W Richter. 1979. Petrology of an eclogitemetarodingite suite at Cima di Gagnone, Ticino, Switzerland. American Mineralogist 64: 15-31

Vidyadharan KT and A Joshi. 1984. Unpublished Geological Survey of India Report. 42p

Vidyadharan KT, A Joshi, S Ghosh, MP Gaur and R Shukla. 1989. Manipur ophiolites: Its geology, tectonic setting and metallogeny. In: Ghose NC (ed.) Phanerozoic ophiolites of India. Patna: Sumna Publication. p197-212 